Cornell Law Library

Scholarship@Cornell Law: A Digital Repository

Cornell Law Faculty Publications

Faculty Scholarship

$10-1-2006$

\title{
Use It or Pretenders Will Abuse It: The Importance of Archival Legal Information
}

Theodore Eisenberg

Cornell Law School, ted-eisenberg@lawschool.cornell.edu

Follow this and additional works at: http://scholarship.law.cornell.edu/facpub

Part of the Law and Society Commons, Legal Writing and Research Commons, and the Politics Commons

\section{Recommended Citation}

Eisenberg, Theodore, "Use It or Pretenders Will Abuse It: The Importance of Archival Legal Information" (2006). Cornell Law Faculty Publications. Paper 360.

http://scholarship.law.cornell.edu/facpub/360

This Article is brought to you for free and open access by the Faculty Scholarship at Scholarship@Cornell Law: A Digital Repository. It has been accepted for inclusion in Cornell Law Faculty Publications by an authorized administrator of Scholarship@Cornell Law: A Digital Repository. For more information, please contact jmp8@cornell.edu. 


\title{
USE IT OR PRETENDERS WILL ABUSE IT: THE IMPORTANCE OF ARCHIVAL LEGAL INFORMATION
}

\author{
Theodore Eisenberg*
}

\section{INTRODUCTION}

Archival information about the legal system should inform policymaking. Despite claims of soaring civil damages awards, modern historical data show no to little growth in tort awards and no real growth in punitive damages awards. The data also show a dramatic forty-year decline in trial rates from more than ten percent of case dispositions to less than two percent. The decline needs to be explained in part by using archival data. Contrary to perceptions underlying the Class Action Fairness Act of $2005^{1}$, little systematic evidence exists that state and federal courts process class actions significantly different. These results contradict the publicity campaigns and empirical studies generated by parties with policy agendas. If society does not preserve accurate information about the legal system, and promote the information's analysis and dissemination, questionable analysis will be supplied to suit the policy agendas of special interest groups. Society would not consider making economic policy without systematic knowledge of past economic experience. Nor would society consider making health care policy without systematic knowledge of past pandemics, epidemics, successful health campaigns, or toxic incidents. Society should demand no less before making legal policy.

Sound policymaking requires information about how the legal system operates. Critical information about its past operation often is not available in published texts, opinions, or routinely maintained databases. This article illustrates what should be obvious - that archival sources can and should inform policymaking. This exercise may be necessary or appropriate because policymakers too often ignore available information and neglect the historical record. Neglecting the historical legal record not only deprives policymakers of useful information. Information vacuums, like natural vacuums, will be filled. Absent reliable information, special interest groups with little incentive to accurately describe the legal system's operation will fill the vacuum with selfserving information and analysis.

Part II of this article discusses long-term patterns in three areas of recent policy discussion: tort awards, trial rates, and class actions. Claims of everincreasing awards persist, both for punitive and compensatory damages. Without access to long-term data about trial-level awards, it is impossible to know how awards have changed. Two data sets illustrate the importance of archival information in describing the long-term trends in awards. The data supply no evidence of a broad-based, real increase in tort awards. The long-term decline in

\footnotetext{
- Henry Allen Mark Professor of Law, Cornell Law School. An earlier version of this paper was presented at a conference sponsored by the University of Missouri-Kansas City Law School and the National Archives and Records Administration-Central Plains Region, Kansas City, October 7-8, 2005.

' Class Action Faimess Act, Pub. L. No., 109-2, 119 Stat. 4 (2005).
} 
trial rates needs to be assessed using historical data about the procedural stages of case disposition. Historical information is least available about class action activity. Recent analysis by researchers at the Federal Judicial Center shows that analysis of case records can illuminate modern class action discussions. Little evidence yet exists that state and federal courts process class certification significantly differently.

Part III explores the uphill struggle to allow historical legal data to tell their story. The results relating to damages awards and class actions contradict the public relations efforts and empirical studies funded by groups with policy agendas. These groups engage in disinformation campaigns that distract from empirical realities. Accurate historical information about legal cases supplies the raw data needed for valid empirical description. Disinterested analysis of the information must be promoted to assure that policymaking is not captured by the policy agendas of well-funded special interest groups.

\section{KNOWLEDGE OF LONG TERM CIVIL LITIGATION TRENDS DEPENDS ON ARCHIVAL DATA}

\section{A. Time Trends in Tort Awards}

As RAND Institute for Civil Justice ("RAND") researchers recently wrote, "It has become standard mantra for proponents of reform to claim that damage awards are simply too high and getting worse, often citing a few high-profile verdicts or some limited statistics to demonstrate a high level of growth in award magnitude." Little empirical support exists for the belief in increasing awards, though it is one of the most repeated claims about the legal system. ${ }^{3}$ A study of products liability awards published about fifteen years ago, during an earlier period of purported tort crisis, indicated that "there was about as much evidence that real-dollar awards in products liability cases had declined as that they had grown."4 Broader databases with comprehensive data across a range of torts indicate that the real value of tort awards has not noticeably increased.

\section{The RAND Institute for Civil Justice Forty-Year Data Set and Tort Awards}

The RAND Institute for Civil Justice preserved data on forty years of tort trial outcomes in San Francisco, California and Cook County, Illinois. These jurisdictions did not have online information systems containing case outcomes going that far back in time. However, RAND maintained data gathered from jury

\footnotetext{
${ }^{2}$ Seth A. Seabury, Nicholas M. Pace \& Robert T. Reville, Forty Years of Civil Jury Verdicts, 1 J. EMPIRICAL LEGAL STUD. 1 (2004).

${ }^{3}$ William haltom \& Michael McCann, Distorting the law: Politics, Media, and the LITIGATION CRISIS 170-71 (2004).

${ }^{4}$ Id. (citing Theodore Eisenberg \& James A. Henderson, Inside the Quiet Revolution in Products Liability, 39 UCLA L. REV. 731 (1992)).
} 
verdict reporters that currently would only be available in legal archives. Analysis of these data by RAND researchers Seth Seabury, Nicholas Pace, and Robert Reville contained results with important implications for modern tort reform discussions.

Figure 1, from Seabury et al.'s Journal of Empirical Legal Studies article, shows the long-term inflation-adjusted time trend. The figure itself contains revealing information. First, real mean awards have increased over time. Median awards showed a lower rate of increase but also rose. Interestingly, through 1989, the real median award had not noticeably increased since 1960 . Yet the 1980s were a period of intense tort reform lobbying and activity, partly based on claims of widespread award increases. Nevertheless, "both the average and median jury awards in tort cases have increased significantly in real terms from 1960-1999."

Figure 1: Average and median damage awards in tort verdicts by year.

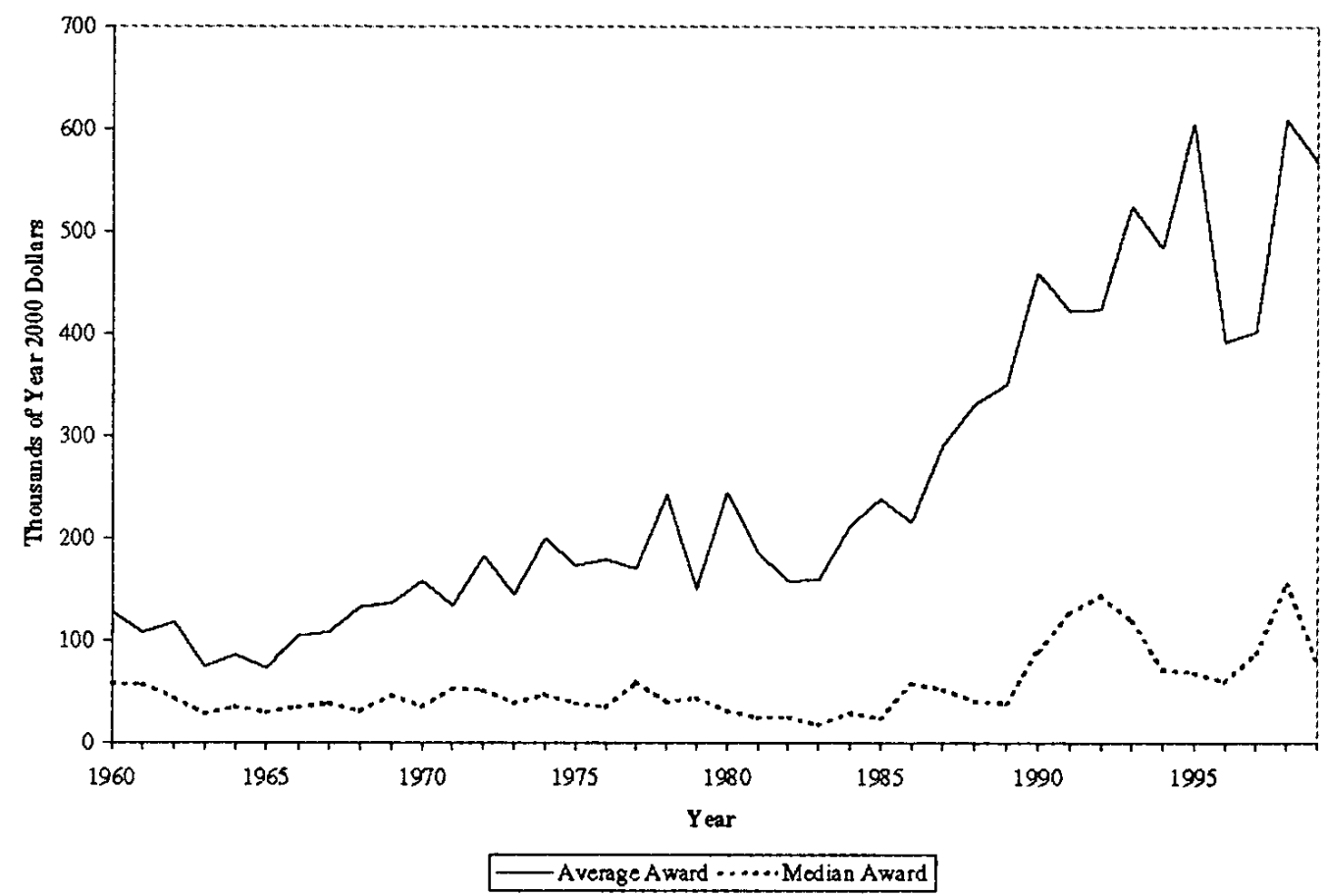

NoTE: The figure includes data on all tort verdicts from San Francisco County and Cook County in which a nonzero award was granted to the plaintiff. The top and bottom 1 percent of awards are trimmed.

Source: Journal of Empirical Studies.

\footnotetext{
${ }^{5}$ Seabury et al., supra note 2, at 3.
} 
More revealing is Seabury et al.'s deeper analysis of the tort verdict data. The abstract for the article states in part:

We find that while there has been a substantial increase in the average award amount in real dollars, much of this trend is explained by changes in the mix of cases, particularly a decreasing fraction of automobile cases and an increase in medical malpractice. Claimed economic losses, in particular claimed medical losses, also explain a great deal of the increase. Although there appears to be some unexplained growth in awards for certain types of cases, this growth is cancelled out on average by declines in awards in other types of cases. ${ }^{6}$

Access to the historical case information allowed the authors to explore the source of the increase in awards. They noted that the mix of cases had changed over time (for example, automobile cases constituted varying proportions of the sample) and that claimed losses had increased. Overall, they found no evidence of noticeably increasing jury awards during this period that spans the modern legal era. "In general, though, the growth (or decline) does not appear substantial enough to support claims of radically changing jury behavior over the past $\mathbf{4 0}$ years.",

The finding by Seabury et al. could not have been documented by normal legal research, which is usually limited to reported opinions. The key to their revealing project was the availability of data from jury verdict outcomes that, for the mass of other cases, only resides in archives. It will be difficult to replicate their results for lengthy time periods for other locales, or for future time periods, even if all records in all courts are preserved. Loss of archival data would result in less informed or misinformed policymaking.

\section{The BJS-NCSC Data on Tort Awards}

The RAND data suggest that, across many areas of tort law, real awards have not increased at all in the modern legal era. But the RAND data cover few locales. Thus, the question remains: What about the trend in the rest of the country's tort awards?

The Civil Justice Survey of State Courts, a project of the National Center for State Courts ("NCSC") and the Bureau of Justice Statistics ("BJS"), presents data gathered directly from state court clerks' offices on tort, contract, and property cases disposed of by trial in fiscal year 1991-1992 and calendar years 1996 and 2001. The three separate data sets cover state courts of general jurisdiction in random samples of forty-five or forty-six of the seventy-five most populous counties in the United States. ${ }^{8}$ The seventy-five counties sampled

\footnotetext{
${ }^{6} I d$.

${ }^{7}$ Id.

8 The 2001 data included forty-six counties; the 1991-92 and 1996 data included forty-five countries. One county included in the 1991-1992 and 1996 study, Norfolk, Massachusetts, fell out the nation's seventy-five most populous in the 2000 census and was replaced by Mecklenburg
} 
include approximately thirty-three percent of the 1990 U.S. population. The actual forty-five counties contributing data account for approximately twenty percent of the population. ${ }^{9}$ The 1991-1992 data include only jury trials. ${ }^{10}$ The 1996 and 2001 data sets include jury and bench trials. The three data sets include all completed trials in most of the counties. Earlier publications describe the sampling in the 1992 and 1996 data sets. " Three counties in the 2001 data set, Cook County, Illinois, Philadelphia County, and Bergen County, New Jersey used sampling. ${ }^{12}$

Table 1 summarizes the time pattern of awards in tort cases in constant 2001 dollars using the consumer price index ("CPI"). It shows some increases over 1991-1992 levels in the mean award but no evidence of increase in the median or in the log transformed mean. A few high awards drive the increase in the means. Indeed, the high mean for 1996 is the consequence of a single large award. Excluding the award yields a mean 1996 award of about $\$ 490,000$. The table suggests an increase in 2001 of mean awards but a substantial decline over time in the median award.

Table 1. Mean and Median State Court Tort Trial Awards Over Time ${ }^{13}$

\begin{tabular}{lccccc} 
Year & Mean award & $\begin{array}{c}\text { Mean award } \\
(\log 10)\end{array}$ & Median award & $\begin{array}{c}\text { Median award } \\
(\log 10)\end{array}$ & $\mathrm{N}$ \\
\cline { 2 - 6 } $1991-92$ & $489,825.8$ & 4.8 & $58,261.0$ & 4.8 & 2219 \\
1996 & $1,239,418.1$ & 4.6 & $37,837.8$ & 4.6 & 2817 \\
2001 & $781,205.3$ & 4.6 & $31,490.0$ & 4.5 & 2835
\end{tabular}

Sources: Bureau of Justice Statistics; National Center for State Courts.

County, North Carolina, and El Paso County, Texas. Two Maryland counties declined to participate in the 1991-1992 study, and were replaced with Fairfax County for all three iterations of the Civil Justice Survey.

${ }^{9}$ For a summary of the data and methodology, see BUREAU OF JUSTICE STATISTICS BULLETIN: CIVIL Justice Survey of State Courts, 2001: Civil Trial Cases and Verdicts in Large Counties, 2001 (April 2004); Bureau of Justice Statistics Bulletin: Civil Justice Survey of State Courts, 1996: Civil Trial Cases and Verdicts in Large Counties (1999); Bureau of Justice Statistics Bulletin: Civil Justice Survey of State Courts, 1992: Tort Cases IN LaRge COUNTIES 6 (1995); Michael Heise, Justice Delayed?: An Empirical Analysis of Civil Case Disposition Time, 50 CASE W. RES. L. REV. 813, 822-27 (2000) (describing 1991-1992 data).

${ }^{10}$ See Heise, supra note 9.

${ }^{11}$ See note 9 supra, and accompanying text.

12 Bureau of Justice Statistics, Civil Trial Cases \& Verdicts in Large Counties, 2001 (2004), http://www.ojp.usdoj.gov/bjs/pub/pdf/ctcvlc01.pdf.

${ }^{13}$ Id. 
Figure 2 is a box-and-whisker plot showing inflation-adjusted total damage awards $(\log 10)$ for the three time periods covered by the NCSC data. ${ }^{14}$ The boxand-whisker plot includes a box designating the 25th and 75th quartiles of the distribution of damages. A horizontal line within the box indicates the median of the distribution. The "whiskers" extend to the farthest points that are within 1.5 times the interquartile range. Each point more than $3 / 2$ times the interquartile range from the end of a box is indicated by a dot. The figure subdivides awards into three groups: motor vehicle cases, non-motor-vehicle bodily injury cases, and non-motor-vehicle non-bodily-injury cases. The figure indicates that, taken as a whole, tort awards declined in motor vehicle cases, and held fairly steady in non-motor-vehicle cases. The absence of evidence of a consistent increase applies for both bodily injury cases and non-bodily-injury cases. ${ }^{15}$

Figure 2. Tort Awards Over Time: 7830 Plaintiff Trial Wins

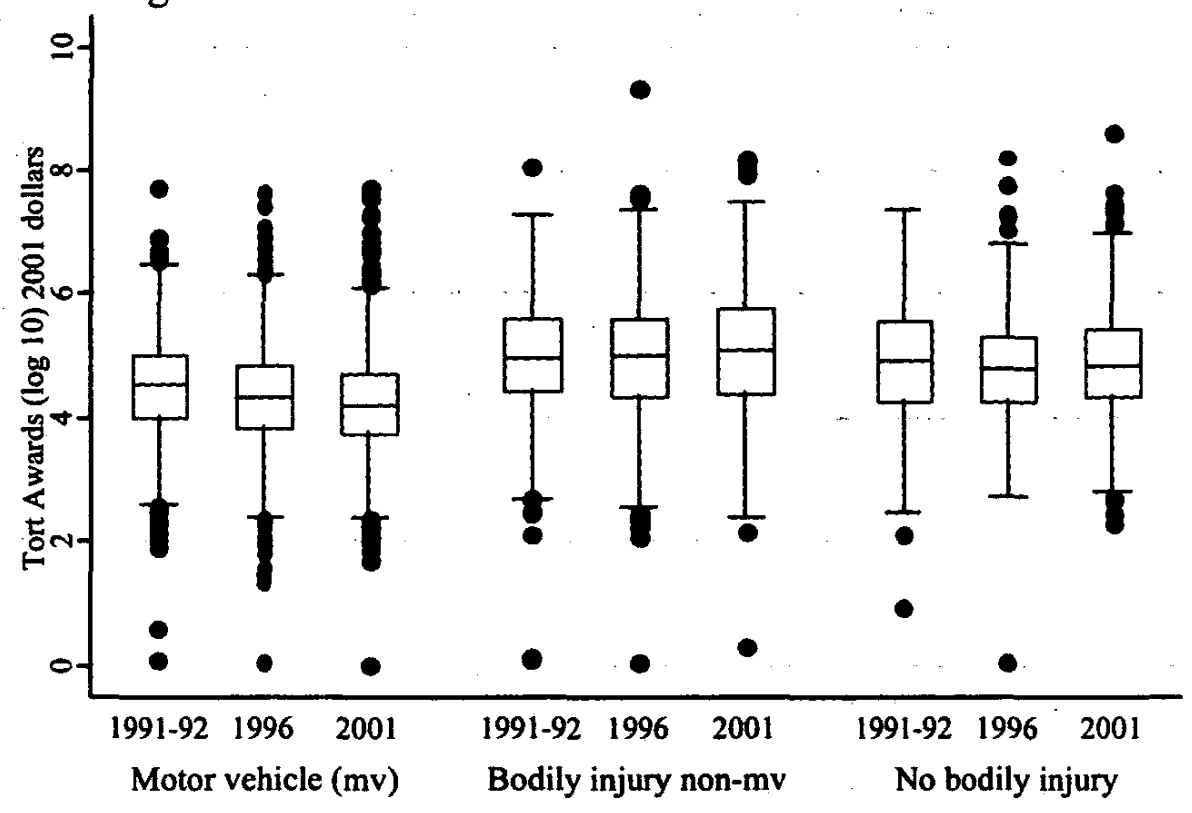

Sources: Bureau of Justice Statistics; National Center for State Courts.

\footnotetext{
${ }^{14}$ See the Bureau of Justice Statistics Bulletins in note 9, supra.

${ }^{15}$ For differences in judge-jury punitive damages award patterns in bodily injury and non-bodilyinjury cases, see Theodore Eisenberg, Paula L.Hannaford-Agor, Michael Heise, Neil LaFountain, G. Thomas Munsterman, Brian Ostrom, and Martin T.Wells, Juries, Judges, and Punitive Damages: Empirical Analyses Using the Civil Justice Survey of State Courts 1992, 1996, and 2001 Data, 3 J. EMPIRICAL LEGAL. STUD. 263, 278-80, 285-88 (2006).
} 
Figure 3 focuses on bodily injury cases. It divides them into products liability cases, medical malpractice cases, and other bodily injury cases. Rather than use the general CPI to adjust for inflation, it uses the medical care component of the CPI. One might expect medical care to be a large component of tort awards in bodily injury cases and medical inflation has outpaced the CPI in recent years. In addition, it is useful to explore the sensitivity of the time pattern of awards to assumptions about inflation. Figure 3 suggests a nonuniform pattern across the three subcategories of bodily injury cases. In the large, most inclusive category, tort awards, if anything, decreased from 1991-1992 to 2001. In medical malpractice cases, even after adjusting for inflation, awards increased. In products liability cases, the picture is mixed, with a decline from 1991-1992 to 1996 and an increase from 1996 to 2001.

Figure 3. Products, Medical \& Other Bodily Injury Tort Awards Over Time

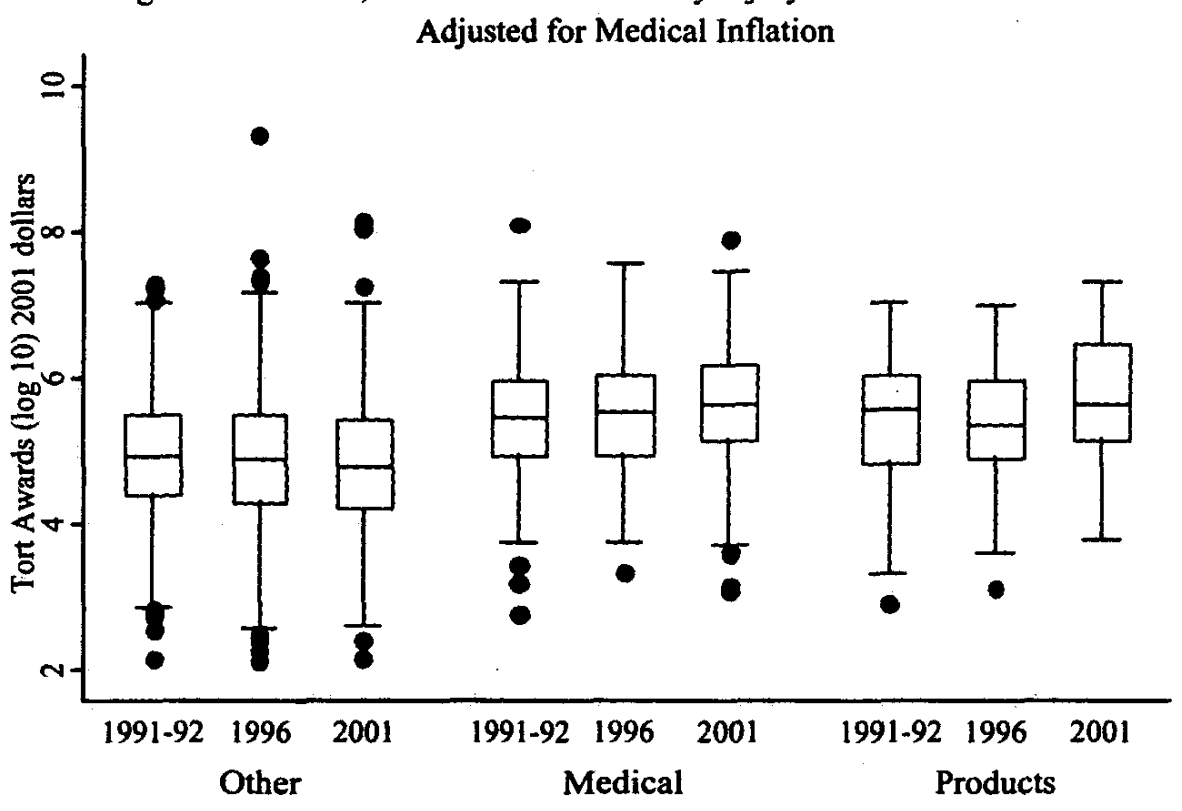

Sources: Bureau of Justice Statistics; National Center for State Courts.

Regression analysis allows one to explore the time pattern more deeply. Table 2 reports regression models exploring the topics discussed above. The variables of primary interest are the two dummy variables for years (1996 and 2001), which assess whether tort awards increased relative to 1991-1992 (the reference category). All models include dummy variables for states (not reported in Table 2). Standard errors are computed based on clustering at the county level. 
[Vol. 75:1

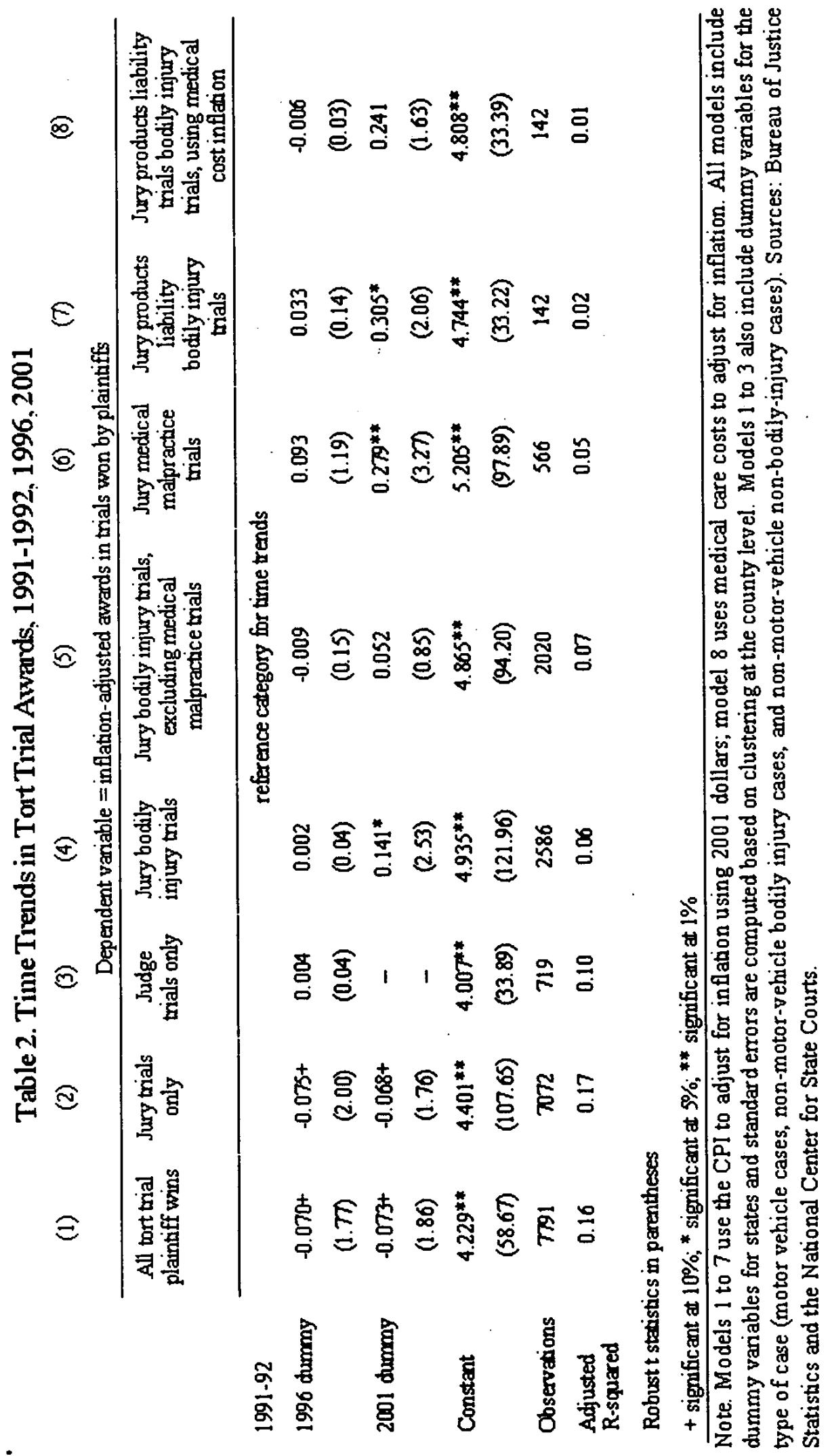


The first three models cover judge and jury trials combined (model 1), jury trials only (model 2), and judge trials only (model 3 ). These three models also include dummy variables for the type of case (motor vehicle cases, non-motorvehicle bodily injury cases, and non-motor-vehicle non-bodily-injury cases). The dependent variable is award amounts $(\log 10)$, adjusted to 2001 dollars using the CPI.

In these three models, the coefficients for 1996 and 2001 dummy variables are small and statistically insignificant. (The judge trials model reports no coefficient for 2001 because judge trials were not included in the 1991-1992 sample. Therefore, the coefficient for the 1996 variable for model 3 assesses the 1996 award level relative to 2001.) The only hints of statistically significant effects are nearly significant declines in trial awards from 1991-1992 to 1996, as shown, for example, in model 2's 1996 dummy variable's being significant at $p=$ .1. Similar declines emerge for 2001 relative to 1991-1992. These three models confirm the core RAND story for Cook County and San Francisco of no evidence of a real increase in awards. They suggest that the absence of evidence covers both judge and jury trials.

Models 4 to 8 in Table 2 explore the bodily injury subset of cases. Model 4 explores the time trend for jury trial bodily injury cases. It shows no large or statistically insignificant increase in awards from 1991-1992 to 1996. But model 4 shows that awards in bodily injury jury trials in 2001 are significantly above their 1991-1992 level.

Model 5 helps identify the source of the award increase in jury trial bodily injury cases. It is identical to model 4, except that the sample in model 5 excludes medical malpractice cases. With that exclusion, the coefficient on the 2001 dummy variable is small and statistically insignificant. Thus, the increase in jury personal injury awards in 2001 appears attributable to growth in medical malpractice awards.

Model 6, limited to medical malpractice jury trials confirms a substantial, significant increase in medical malpractice awards from 1991/1992 through 2001, with no significant increase from 1991/1992 through 1996. In a model not reported here, the awards were adjusted to account for medical care inflation rather than the more general CPI measure of inflation. Medical awards still showed a real and statistically significant increase in 2001.

Model 7 limits the sample to jury trial products liability cases. They, like medical malpractice cases in model 6, show an insignificant 1996 effect relative to years 1991-1992 and a significant 2001 effect. But model 8, which uses medical care costs to adjust for inflation, shows that the 2001 effect is not robust to the choice of inflation adjustment. If medical costs are a substantial component of damages in products liability cases, then the data contain little evidence of a statistically significant increase in real products liability awards in 2001 relative to $1991 / 1992$.

Taken together the historical record is reasonably consistent. Both the RAND data and the BJS data suggest no extraordinary long-term growth in overall tort trial awards.

Medical malpractice trial awards did increase in real dollars from $1991 / 1992$ to 2001 . The compound annual real growth in the median award was 
about four percent per year over medical cost inflation. This increase is consistent with other reports of trial awards in medical malpractice cases. For example, a study of Texas medical malpractice cases by Black et al. found that real jury trial awards increased by an estimated 2.5 to 3.6 percent per year from 1988 to 2002 . $^{16}$ A study of Florida medical malpractice cases by Vidmar et al. found that mean (median) payments for paid claims, in real 2003 dollars, increased from $\$ 177,000(\$ 49,000)$ in 1990 to $\$ 300,000(\$ 150,000)$ in 2003. ${ }^{17}$

The explanation for the medical malpractice award increase remains a subject of research. Black et al. found "little or no trend in post-trial payout amounts" but the authors plan to further study the matter. ${ }^{18}$ They suggest that, perhaps due to increased litigation costs, "smaller claims are being squeezed out of the med mal system." 19 Vidmar et al. attribute award growth to a significant increase in the severity of the injuries claimants sustained, and larger awards within injury-severity categories, possibly driven by the growing cost of health care. $^{20}$ The RAND forty-year study of tort awards also mentions increases in claimed economic medial losses as an explanation of the medical awards increase. ${ }^{21}$ Thus, changes in jury behavior or in the distribution of likely awards in the medical malpractice cases pursued to trial, or both, may have caused an increase in awards, but further study is needed. The central point here is that detecting important long-term trends in tort awards requires access to individual case data in the mass of tried cases.

\section{Trends in Punitive Damages}

The painstaking job of gathering data from primary court records has yielded further insight about the tort system. One area of persistent policy debate is the level and time pattern of punitive damages.

Figure 4 is a box-and-whisker plot showing CPI inflation-adjusted punitive damage awards $(\log 10){ }^{22}$ As in Figures 2 and 3, the boxes designate the 25th and 75th quartiles of the distribution of damages and the line in the box represents the median award. The figure reports awards for each of the three time periods for which BJS-NCSC data are available. It further divides awards by judge and jury trials for the two years, 1996 and 2001, for which judge trial data are available.

\footnotetext{
16 Bernard Black, Charles Silver, David A. Hyman \& William M. Sage, Stability, Not Crisis: Medical Malpractice Claim Outcomes in Texas, 1988-2002, 2 J. EMPIRICAL LEGAL STUD. 207 (2005).

${ }^{17}$ Neil Vidmar, Paul Lee, Kara MacKillop, Kieran McCarthy, and Gerald McGwin, Seeking the "Invisible" Profile of Medical Malpractice Litigation: Insights from Florida, 54 DEPAUL L. REV. 315 (2005).

${ }^{18}$ Black et al., supra note 16 , at $221,251$.

${ }^{19} \mathrm{Id}$.

${ }^{20}$ Vidmar et al., supra note 17.

${ }^{21}$ Seabury et al., supra note 2, at 1.

${ }^{22}$ See the Bureau of Justice Statistics Bulletins in note 9, supra.
} 


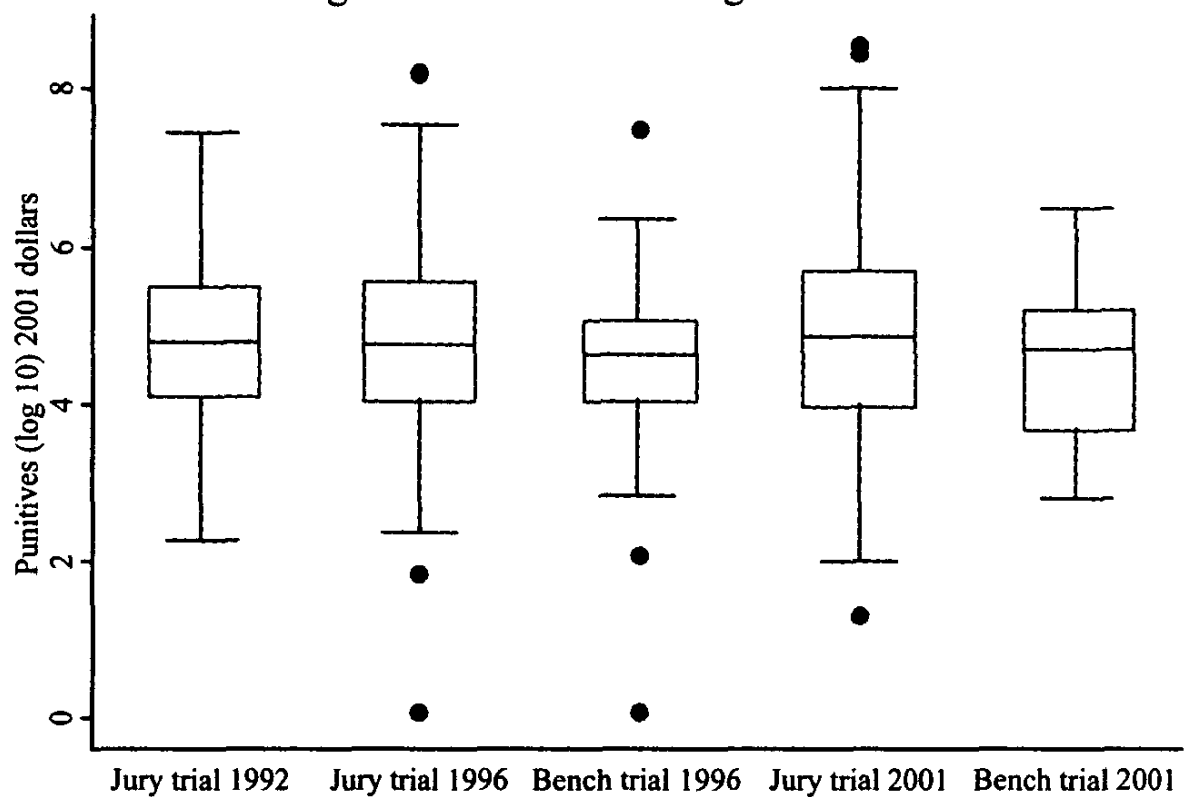

Sources: Bureau of Justice Statistics; National Center for State Courts.

Figure 4 shows that punitive damages awards have been stable over the decade covered by the data (assuming no wild fluctuation occurred in the years between the observed years). All of the interquartile ranges substantially overlap. All of the medians are close to one another. Thus, during the decade studied, punitive damages did not materially increase in this large sample of state court litigation. These results can only be reliably detected by access to detailed court data.

\section{B. Accurate Measures of Non-Trial Litigation Activity}

The importance of archival court data extends beyond award amounts. The procedural stage of case disposition is also of interest. It is well known that the vast majority of cases do not reach trial. Trial rates in federal and state courts have shown a long-term and dramatic decline. ${ }^{23}$ The percent of federal civil terminations during or after trial decreased from about twelve percent in the 1960 s to less than two percent in recent years. ${ }^{24}$ There were fewer federal civil

${ }^{23}$ Marc Galanter, The Vanishing Trial: An Examination of Trials and Related Matters in Federal and State Courts, 1 J. EMPIRICAL Legal STUD. 459 (2004); Brian J. Ostrom, Shauna M. Strickland, \& Paula L. Hannaford-Agor, Examining Trial Trends in State Courts 1976-2002, 1 J. EMPIRICAL LEGAL STUD. 755 (2004).

${ }^{24}$ Galanter, supra note 23 , at 465 . 
trials in federal district courts in 2002 than in the $1960 \mathrm{~s}^{25}$ State court trial rates also decreased. ${ }^{26}$

Filings have not decreased nearly as dramatically as trials. What has happened to all the cases? Some observers simplistically assume that all cases that do not reach trial settle. Reports exist of a ninety percent settlement rate. ${ }^{27}$ As Marc Galanter has written, "Both popular speech and a great deal of scholarly discourse proceed as if the universe of disposition is made up of trial and settlement, so that a decline in trials must mean an increase in settlements.",28

That a case does not reach trial does not necessarily mean that the case settled. Little is known about the mass of cases that are filed but do not reach trial. Information about the settlement rate (assuming there were one meaningful settlement rate across different categories of civil litigation) is not readily available for long-term time periods across a broad geographical base. A few studies provide a reasonably accurate measure of settlement patterns ${ }^{29}$ but such data are not systematically available. Since geographic variation in legal outcomes seems to constitute the rule, rather than the exception, ${ }^{30}$ broad-based databases are necessary. So little systematic knowledge of nontrial dispositions exists that we cannot even be sure that settlement rates have increased while trial rates have decreased. ${ }^{31}$

Thus, trials may be being replaced, not by settlements, but by some combination of nontrial adjudication, alternative dispute resolution, administrative adjudication, and other factors. ${ }^{32}$ The different possible influences on vanishing trials have important implications. If nontrial adjudications are substantially increasing, then the judge is disposing of more cases. In settled cases, the parties resolve their disputes. In tried cases, in which parties at least have the option of having a jury trial, the jury plays a role. In nontrial, non-

${ }^{25}$ Galanter, supra note 23 , at 464.

${ }^{26} \mathrm{Id}$; Ostrom, supra note 23, at 769-73.

${ }^{27}$ Gillian Hadfield, Where Have All the Trials Gone? Settlements, Nontrial Adjudications, and Statistical Artifacts in the Changing Disposition of Federal Civil Cases, 1 J. EMPIRICAL LEGAL STUD. 705, 706 (2004) ("few get through law school without hearing at least one professor tell them that only ' 5 percent of cases go to trial; 95 percent settle."') (internal citation omitted).

${ }^{28}$ Galanter, supra note 23, at 482-83 (footnote omitted).

${ }^{29}$ For estimates of settlement rates and the difficulty in ascertaining such rates, see Theodore Eisenberg \& Stewart Schwab, Explaining Constitutional Tort Litigation: The Influence of the Attorney Fees Statute and the Government as Defendant, 73 CORNELL L. REV. 719 (1988); Hadfield, supra note 27; Herbert M. Kritzer, Adjudication to Settlement: Shading in the Gray, 70 JUDICATURE 161 (1986).

${ }^{30}$ Theodore Eisenberg \& Martin T. Wells, The Predictability of Punitive Damages, 26 J. LEGAL STUD. 623, 631 (1997).

${ }^{31}$ Hadfield, supra note 27, at 705 (referring to, "surprising [possible] conclusions that a smaller percentage of cases were disposed of through settlement in 2000 than was the case in 1970, that vanishing trials have been replaced not by settlements but by nontrial adjudication, and that it is the bench, not jury, trial that has been transformed in this way").

${ }^{32}$ See 3 JourNal of EMPIRICAL LEGAL STUD. 3 (2004) for many perspectives on the vanishing trial phenomenon. 
settlement dispositions, the judge acts alone. Given the low rates of appeals and reversals, ${ }^{33}$ in the vast majority of cases, the trial judge's verdict is effectively final. An increasing rate at which a single individual's view finally resolves disputes is important information for policymakers. This may suggest why, and perhaps justify, the increasing time spent in considering and confirming judges. ${ }^{34}$

This is not the occasion to explore in detail the cause of the reduction in trials. The mode of pretrial disposition can only be explored through access to court records in the mass of cases.

\section{Assessing Class Action Activity}

Class action litigation is a debated civil justice topic in recent years. Major class action reform legislation includes the Private Securities Litigation Reform Act of $1995^{35}$ and the Class Action Faimess Act of 2005 ("CAFA"). "Strikingly little is known about the actual operation of the class action system, especially outside the area of securities litigation. When the Federal Judicial Center ("FJC") was charged with examining class action litigation, it found existing databases unsatisfactory. ${ }^{37}$ The FJC researchers, Thomas Willging, Laural Hooper, and Robert Niemic, found that the basic federal court system database code for class actions missed most class action cases. ${ }^{38}$ The labor-intensive effort limited the study to four federal districts in major urban areas (Philadelphia, Miami, Chicago, and San Francisco) and to class action cases (not just published opinions) terminated from July 1, 1992 through June 30, $1994 .^{39}$

This 1996 report found that most class actions settled, that individual recovery levels were small, that attorney fees rarely exceeded the traditional onethird contingency fee, and that settlements of no value to the class members were very rare. ${ }^{40}$ The authors concluded that, "without an aggregative procedure like the class action, the average recovery per class member or even the maximum recovery per class member seems unlikely to be enough to support individual

${ }^{33}$ Kevin M. Clermont \& Theodore Eisenberg, Plaintiphobia in the Appellate Courts: Civil Rights Really Do Differ from Negotiable Instruments, 2002 UNIV. ILL. L. REV. 947; Kevin M. Clermont \& Theodore Eisenberg, Appeal from Jury or Judge Trial: Defendants' Advantage, 3 AM. L. \& EcoN. REV. 125, 130 (2001); Kevin M. Clermont \& Theodore Eisenberg, Anti-Plaintiff Bias in the Federal Appellate Courts, 84 JudiCATURE 128 (2000); Theodore Eisenberg, Appeal Rates and Outcomes in Tried and Nontried Cases: Further Exploration of Anti-Plaintiff Appellate Outcomes, 1 J. EMPIRICAL LEgAL STUD. 659 (2004).

34 John R. Lott Jr., The Judicial Confirmation Process: The Difficulty with Being Smart, 2 J. EMPIRICAL LEGAL STUD. 407 (2005).

35 Pub. L. No. 104-67, 109 Stat. 737 (1995) (codified in 15 U.S.C. $\$ \S 77,78$ ).

${ }^{36}$ Pub. L. No. 109-2, 119 Stat. 4 (2005).

37 Thomas E. Willging, Laural L. HoOper, \& Robert J. Niemic, Empirical Study of Class ACtions in Four Federal District Courts: Final Report to the Advisory Committee on Crvil Rules 198 (Federal Judicial Center 1996).

${ }^{38} I d$.

${ }^{39} \mathrm{Id}$.

${ }^{40} I d$. 
actions in most, if not all, of the cases studied., ${ }^{, 11}$ A national study of a decade of published opinions in class action cases found that class actions likely netted class members more than individual actions would, recoveries and attorney fees in class actions were stable over a ten-year period from 1993 to 2002, and that low-value recoveries were rare. ${ }^{42}$ A similar study found, as did the 1996 FJC study, that recoveries per class member were generally too low to expect individuals to seek legal redress on their own. ${ }^{43}$

Willging and Shannon R. Wheatman of the FJC published another class action study in 2005 with important information about the most visible class action question of the time period: possible differences between class action treatment by federal and state courts. ${ }^{44}$ The methodology for finding cases was improved by electronic access to archival data. The authors made use of the LexisNexis CourtLink database to locate 15,037 class action cases from eightytwo federal districts linked to the PACER system; ${ }^{45} 6,386$ cases were terminated between July 1, 1999 and December 31, 2002.

Using cases from this 3.5 year period, the 2005 FJC study confirmed in a broad sample that settlements of little value to class members were rare. ${ }^{46}$ The study also revealed that the typical recovery or settlement was $\$ 800,000,{ }^{47}$ well below the typical recovery of millions of dollars in the subset of class action cases reported in published opinions. ${ }^{48}$

Of most relevance to recent class action legislation, the FJC study authors surveyed plaintiff and defendant attorneys to study differences in judicial treatment of class actions based on attorney perceptions of whether state or federal courts were more favorable. State court case outcomes studied consisted of cases that had been removed to federal court and remanded to state court. Federal case outcomes studied consisted of actions removed from state court and adjudicated in federal court. ${ }^{49}$ The authors compared case outcomes for four classes of remanded and removed cases: (1) class certification rulings where plaintiff attorneys perceived a judicial predisposition in state court in favor of

${ }^{41} I d$.

${ }^{42}$ Theodore Eisenberg \& Geoffrey P. Miller, Attorney Fees in Class Action Settlements: An Empirical Study, 1 J. EMPIRICAL LEGAL STUD. 27 (2004).

${ }^{43}$ Theodore Eisenberg \& Geoffrey P. Miller, The Role of Opt-Outs and Objectors in Class Action Litigation: Theoretical and Empirical Issues, 57 VANDERBILT L. REV. 1529 (2004).

44 Thomas E. Willging \& Shannon R. Wheatman, An Empirical Examination of ATtorneys' ChOICE of Forum IN Class ACTION Litigation (Federal Judicial Center 2005).

${ }^{45} I d$.

${ }^{46} \mathrm{Id}$.

${ }^{47} \mathrm{Id}$.

${ }^{48}$ Eisenberg \& Miller, supra note 42, at 47-48.

${ }^{49}$ WILLGING \& WHEATMAN, supra note 44 , at $42-46$. It appears that many state court defendants do not hesitate to remove cases from federal to state court, even when removal is wrongful. Theodore Eisenberg \& Trevor Morrison, Overlooked in the Tort Reform Debate: The Growth of Erroneous Removal, 2 J. EMPIRICAL LEGAL STUD. 551 (2005). So the FJC researchers' comparison of removed cases retained in federal court and removed cases remanded to state court should pick up a reasonably broad cross-section of class action activity. 
plaintiff, (2) class certification rulings where defendant attorneys perceived a judicial predisposition in federal court in favor of defendant, (3) outcomes in noncertified class actions where a plaintiff attorney perceived a judicial predisposition in state court in favor of plaintiffs, and (4) outcomes in noncertified class actions where a defendant attorney perceived a judicial predisposition in federal court in favor of defendants. ${ }^{50}$ For each of these four classes of cases, the authors compared the rulings in cases removed to federal court and remanded to state court with the rulings in cases removed to federal court and not remanded to state court. For each group of cases, the authors identified an attorney-perceived judicial bias towards plaintiffs or defendants and the authors were able to compare how state and federal judges ruled in light of those perceived biases.

In light of tort reform advocates' attack on state court behavior in class actions, ${ }^{51}$ the results of the FJC researchers' analysis are remarkable. Where plaintiffs' attorneys perceived state court favoritism to plaintiffs, "plaintiffs in fact received comparable rulings from state and federal courts on the central issue of whether or not to certify a class." 52 Defendants' attorneys were no better at predicting state/federal court differences. "[D]efendant attorneys' statements about judicial predispositions yielded no significant differences in the likelihood that a federal or state court would certify a class." 33 Federal judges in fact certified classes slightly more often than state judges-in the very cases in which defendant attorneys indicated that federal courts would favor defendants. Outcomes in noncertified cases yielded similar results. ${ }^{54}$

The FJC researchers summarized their findings as follows:

Attorney perceptions of judicial predispositions toward their clients' interests show little or no relationship to the judicial rulings in the surveyed cases, even when we grouped the cases according to the direction of the perceived predispositions. Judges certified or dismissed class actions with equivalent frequency in state and federal courts. The sole difference was that judges in federal courts more frequently denied certification while state courts more frequently took no action on class certification. ${ }^{55}$

Thus, the best available information about comparative state/federal judicial performance in class actions suggests no strong differences.

Willging and Wheatman substantially improved the methodology of studying class actions by exploiting the PACER system to access archival federal court data. The Willging and Wheatman study should influence the methodology in future empirical studies of federal case outcomes.

\footnotetext{
${ }^{50}$ WILLGING \& WHEATMAN, supra note 44 , at 42-45.

${ }^{51}$ See e.g., John H. Beisner \& Jessica Davidson Miller, They're Making a Federal Case out of it . . . in State Court, Harvard J. L. \& Public Policy 143 (2001).

${ }^{52}$ Id. at 42.

${ }^{53} \mathrm{Id}$. at 43.

${ }^{54} \mathrm{Id}$. at $44-45$.

${ }^{55}$ Id. at 46.
} 


\section{INFORMATION GAPS WILL BE FILLED WITH LESS ACCURATE AND BIASED INFORMATION}

The stakes of preserving and using detailed information about cases exceed mere preservation of the historical record. Reliable information about the legal system is essential to understanding how the legal system works. Without reliable information, those with agendas and resources to pursue them will fill information gaps as their legislative and policy desires require. Access to archival data does more than offer a choice between little information about how the legal system operates and substantial, accurate information. The choice with respect to issues of policy interest is not between information and no information. The true choice often is between accurate information and self-interested, biased information paid for and gathered with a purpose in mind.

For three of the areas discussed above-tort awards, punitive damages awards, and class actions, broad unbiased information is necessary to inform policymakers who otherwise will only be informed by systematic, well-funded studies whose sponsors seek to discredit decisionmaking by judges, juries, and locales.

\section{A. "America's Lawsuit Culture"}

Before considering specific and questionable empirical evaluations of the legal system, it is helpful to explore a root source of disaffection with the legal system-the perception that the U.S. population is litigious. In congressional hearings on one of the tort reform proposals of the last few decades, I testified ${ }^{56}$ on a panel with the author of a "national bestseller." $"$ He was an intelligent, articulate, and concerned citizen. He spoke in favor a proposal that would massively shift judicial power to the federal government and away from the states. ${ }^{58}$. But he unwittingly illustrated a failure of legal education in the U.S. This witness-author clearly knew little, at a macro level, about how the relevant portions of the legal system actually operate. It is not his fault. No one-lawyer, policymaker, judge, or academic-is required to know about any of the many empirical studies that help document what actually occurs in the legal system. Lawyers and judges will have passed a bar exam that requires no such knowledge, and attended law schools that offer no courses on the subject.

The witness, like most of us, apparently did not know that tort lawsuits have been in a long-term decline. Across thirty-five states representing about seventyseven percent of the national population, tort filings decreased by four percent

\footnotetext{
${ }^{56}$ Safeguarding Americans From a Legal Culture of Fear: Approaches to Limiting Lawsuit Abuse: Oversight Hearing Before the H. Comm. on the Judiciary, 109th Cong. 109-123 (2005) (statement of Theodore Eisenberg, Professor of Law at Cornell Law School).

57 PhILIP K. Howard, The Collapse of the COMmon Good: How America's lawsuit Culture UNDERMINES OUR FREEDOM (2001). The cover of the paperback edition of Mr. Howard's book states that Mr. Howard is the author of the national bestseller THE DEATH OF COMMON SENSE.

${ }^{58}$ Lawsuit Abuse Reduction Act of 2004, H.R. 4571, 108th Cong. (2004).
} 
between 1993 and $2002 .^{59}$ The witness did not report that the best available data does not rank the U.S. among the most litigious countries, ${ }^{60}$ did not report that serious studies of litigiousness do not find Americans, ${ }^{61}$ or others, ${ }^{62}$ particularly eager to sue, and did not report "that eight times as many patients suffer an jury from medical negligence as there are malpractice claims. ${ }^{, 63}$ Most people, in fact, "lump it" after suffering an actionable wrong. Yet the witness had written a book with the subtitle, "How America's Lawsuit Culture Undermines Our Freedom." In the book, and in his congressional testimony, he evidenced awareness of none of the above-relevant facts about the legal system. Yet he was chosen to testify before Congress to inform policymakers. If we educated our leading scientists as incompletely as we educate the legal system's actors, we might still be proving that the earth is flat.

The sad fact is that knowledge of the aggregate functioning of the U.S. legal system, even for most actors in it, rarely extends beyond newspaper headlines. That knowledge gap will be filled by those with an agenda unless archival data and current data are preserved and accessible.

\section{B. Increasing Tort Awards}

Part I discusses some of the best available data about the reality of time trends in tort awards. Little or no evidence exists of broad-based, systematic and long-term increases in tort awards. Yet one of the publicity achievements of the tort reform movement has been to convince America that tort awards have relentlessly increased. William Haltom and Michael McCann have documented perceptions and reporting about awards during the tort reformers' campaign against the tort system. Skyrocketing civil awards are one of the messages that tort reform proponents have managed frequently to insert in major media coverage. $^{64}$

Thus, even with contrary evidence painstakingly extracted from data sources, the tort reform message of soaring damages has successfully been

59 Examining the Work of State Courts, 2003: A National Perspective from the Court Statistics Project 23 (2004).

${ }^{60}$ Herbert M. Kritzer, What we Know and Do Not Know About the Impact of Civil Justice on the American Economy and Policy: Lawyer Fees and Lawyer Behavior in Litigation: What Does the Empirical Literature Really Say?, 80 TEX. L. REV. 1943, 1981 (2002).

${ }^{61}$ Deborah R. Hensler, M. Susan Marquis, Allan F. Abrahamse, SANDra H. Berry, Patricia A. Ebener, Elizabeth G. Lewis, E. Allen LIND, Robert J. MacCoun, Willard G. Manning, JEANNETTE A. Rogowski \& MARY E. VaIANa, COMPENSATION FOR ACCIDENTAL INJURIES IN THE UNITED STATES 121 (1991).

${ }^{62}$ Pascoe Pleasance, Nigel J. Balmer, Alexy Buck, Aoife O'Grady, and Hazel Genn, Multiple Justiciable Problems: Common Clusters and Their Social and Demographic Indicators, $1 \mathrm{~J}$. EMPIRICAL LEGAL STUd. 301 (2004).

${ }^{63}$ Harvard Medical Practice Study, Patients, Doctors, and Lawyers: Medical Injury, Malpractice Litigation, and Patient Compensation in New York, The Report of the Harvard Medical Practice Study to the State of New York 7-1 (1990).

${ }^{64}$ HALTOM \& MCCANN, supra note 3, at 170-71, 246. 
implanted in the public consciousness. Information from court records at least allows some systematic refutation of the misleading claims. Without actual data, the misinformers would be even more dominant.

\section{The McDonald's Case and ExxonMobil's Punitive Damages Campaign}

In one area of tort, punitive damages, efforts to fill information voids have transcended purchasing misleading advertisements or feeding the media misleading or distorted information. In state legislative hearings, I witnessed a leading tort reform proponent, while wrapping himself in the garb of academic neutrality, deceptively refer to the punitive and compensatory damages award to 79 -year-old Stella Liebeck in the McDonald's coffee spill case ${ }^{65}$ as a prime reason for tort reform. The rather sober and reasonably explicable decision of jurors to award Liebeck compensatory and punitive damages was explained in a Wall Street Journal article by Andrea Gerlin and further explored by Haltom and McCann. ${ }^{66}$ The public record is clear that, even if one personally would have decided the case differently, the case cannot reasonably be a poster-case for tort reform. Using the case either stems from unquestioning acceptance of oversimplified news coverage or from intentional exploitation of that coverage. Tort reformers have not hesitated to shamefully exploit the painful groin injuries of Ms. Liebeck, a non-litigious octogenarian. As reported by Haltom \& McCann:

While the appointed spokespersons and spinners for tort reform did not influence the initial phases of the public interpretation, they subsequently had a field day with the McDonald's coffee case. " Tort reformers . . gleefully seized on the case as the epitome of frivolity," confirms one observer . ... The incident became a staple on the list of "horror stories"" maintained by the American Tort Reform Association (ATRA) and others. ATRA bought radio ads invoking the coffee case as a prime example of litigation run amok . ... Reporters have told us in interviews that the McDonald's coffee case quickly became a routine component in the standard tort reform literature regularly fed to the press. ${ }^{67}$

Presciently, in light of its subsequent merger with Exxon, ${ }^{68}$ Mobil Oil was alert to exploit the McDonald's case. According to Haltom and McCann, in 1995

\footnotetext{
${ }^{65}$ Liebeck v. McDonald's Restaurants, P.T.S., Inc., No. CV 93-02419, 1995 WL 360309 (D.N.M. Aug. 18, 1994).

${ }^{66}$ Andrea Gerlin, A Matter of Degree: How a Jury Decided That a Coffee Spill Is Worth \$2.9 Million, Wall St. J., Sept. 1, 1994, at A1. For an in-depth discussion of the case, See HaLtom \& MCCANN, supra note 3, at 183-226. See also Neil Vidmar, Felicia Gross, and Mary Rose, Jury Awards for Medical Malpractice and Post-verdict Adjustments of Those Awards, 48 DEPAUL L. REV. 265, 266 (1968); Samuel R. Gross \& Kent D. Syverud, Don't Try: Civil Jury Verdicts in a System Geared to Settlement, 44 UCLA L. REV. 1, 4 (1996).

${ }^{67}$ HaLTOM \& MCCANN, supra note 3, at 223 (citations omitted).

${ }^{68}$ Exxon and Mobil Oil announced merger plans in 1998.
} 
Mobil Oil "took out a substantial advertisement in the New York Times that cited the case, noting that nearly $\$ 3$ million was awarded to a customer who spilled hot coffee on herself." Mobil Oil's publicity attack on a punitive damages case would be only the beginning of its corporate involvement in trying to reshape perception of this issue.

As a result of the 1989 Exxon Valdez oil spill, Mobil Oil's future merger partner, Exxon, had suffered an adverse judgment that included $\$ 5$ billion in punitive damages. ${ }^{70}$ Exxon's (now ExxonMobil) resulting attack on juries opened an interesting new chapter in the effort to generate favorable, selfinterested information about the legal system. Exxon went beyond simple advertising or misleading legislative testimony. It sought to revamp the basic social scientific record.

Exxon funded a massive legal research program that assessed the state of punitive damages in the legal system. The empirical component of that program is of primary interest here. It led to several law review articles in law journals and culminated in a book. ${ }^{71}$ That research was used by Exxon to challenge legal rulings against it. ${ }^{72}$ The Exxon-funded research program also culminated in a Supreme Court brief in State Farm Mut. Auto. Ins. Co. v. Campbell that relied almost exclusively on the corporate-funded research. ${ }^{73}$ The bottom-line conclusion of the Exxon research program: "juries produce systematically erratic and unpredictable awards."74

The Exxon conclusion contradicts massive social science evidence, much of it gained through hard, archival-like research. ${ }^{75}$ A consistent finding across more than a dozen studies is that juries infrequently award punitive damages. ${ }^{76}$ The studies include several multistate studies by government agencies (the BJS in both 2000 and $1995^{77}$ and the U.S. General Accounting Office ("GAO")), ${ }^{78}$ the

${ }^{69}$ HALTOM \& MCCANN, supra note 3, at 224.

${ }^{70}$ In re Exxon Valdez, No. A89-0095-CV, 1995 U.S. Dist. LEXIS 12952 (D. Alaska Jan. 27, 1995). The case has a voluminous subsequent history and the resolution of the punitive damages claim is pending as of this writing.

7 Cass R. Sunstein, Reid Hastie, John W. Payne, David A. Schkade \& W. Kip Viscusi, Punitive Damages: How JuRIES Decide (2002).

${ }^{72}$ Elizabeth Amon, Exxon Bankrolls Critics of Punitives, Then It Cites the Research in Appeal of $\$ 5.3$ Billion Valdez Award, NAT'L. L.J., May 17, 1999, at A1.

${ }^{73}$ Brief of Certain Leading Business Corporations as Amici Curiae in Support of Petitioner, State Farm Mut. Auto. Ins. Co. v. Campbell, 538 U.S. 408 (2003) (No. 01-1289)

${ }^{74}$ Brief, supra note 73, at 2.

${ }^{75}$ Parts of this paragraph are based on Brief of Certain Leading Social Scientists as Amici Curiae, State Farm Mut. Auto. Ins. Co. v. Campbell, 538 U.S. 408 (2003) (No. 01 -2189).

${ }^{76}$ See, e.g., HaLtom \& MCCANN, supra note 3, at 97 ("finding after finding has revealed that punitive damages have rarely been awarded and even more rarely collected") (emphasis in original).

77 U.S. DePT. of Justice BJS Bulletin, Civil Justice SuRvey of State Courts, 1996: TORT TRIALS AND VERDICTS IN LARGE Counties, p. 1 (August 2000) [hereinafter "BJS 2000"] (about three percent of plaintiff winners in tort trials were awarded punitive damages; median award was $\$ 38,000)$; BJS Special Report, Civil Justice Survey of State Courts, 1992: Civil JuRy Cases 
American Bar Foundation, ${ }^{79}$ the RAND Institute of Civil Justice, ${ }^{80}$ by Judge Richard Posner and Professor William Landes, ${ }^{81}$ and others. ${ }^{82}$ Five individual states and county level studies found that punitive awards are not frequent. ${ }^{83}$ Juries award punitive damages more frequently in intentional tort cases. ${ }^{84}$ That is appropriate because intentional torts merit greater punishment than unintentional torts and thus "provide particularly appropriate cases for punitive damages awards." On the infrequent occasions when juries do award punitive damages,

AND VERDICTS IN LARGE COUNTIES (1995), p.1 [hereinafter "BJS 1995"] (about six percent of plaintiff winners received a punitive award; median award was $\$ 50,000$ ).

${ }^{78}$ U.S. GAO, Product Liability Verdicts and Case Resolution in Five States, GaO/HRD-89. 90 (Sept. 1989) 24, 29 (punitive damages awarded in 23 of 305 cases decided in five states) [hereinafter "GAO Report"].

79 STEPHEn Daniels \& JoANne Martin, Civil Juries and the Politics OF Reform 214 (1995) ("punitive damage award activity suggests . . . the need for ... skepticism with regard to claims about the increasing frequency of such awards").

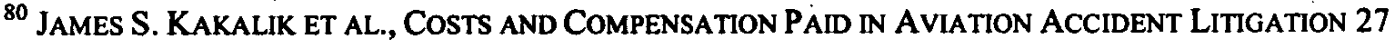
(RAND 1988) ("punitive damages were not paid on any of the 2,198 closed cases"); ERIK MOLLER, TRENDS IN CIVIL JURY VERDICTS SINCE 198533 (RAND 1996) ("punitive damages are awarded very rarely"); Mark Peterson, Syam Sarma \& Michael Shanley, Punitive Damages: EMPIRICAL FINDINGS 10 (RAND 1987) (fewer than seven punitive damages awards per year in Cook County and fewer than six in San Francisco from 1960-1984).

${ }^{81}$ William M. Landes \& Richard A. Posner, The Economic Structure of Tort LaW 304-07 (1987) ("insignificance of punitive damages in our sample is evidence that they are not being routinely awarded").

82 Eisenberg \& Wells, supra note 30, at 633-37 (summarizing studies on the decision to award punitive damages); Theodore Eisenberg et al., Juries, Judges, and Punitive Damages: An Empirical Study, 87 CoRnell L. Rev. 743, 745 (2002); Thomas Koenig \& Michael Rustad, The Quiet Revolution Revisited: An Empirical Study of the Impact of State Tort Reform of Punitive Damages in Products Liability, 16 Justice System J. 21 (1993); Michael Rustad \& Thomas Koenig, Reconceptualizing Punitive Damages in Medical Malpractice: Targeting Amoral Corporations, Not "Moral Monsters," 47 Rutgers L. REv. 975, $981-92$ (1995) (punitive damages rarely awarded in medical malpractice cases).

${ }^{83}$ For example, a recent Georgia study concludes, "punitive damages currently are not a significant factor in personal injury litigation in Georgia." Thomas A. Eaton et al., Another Brick in the Wall: An Empirical Look at Georgia Tort Litigation in the 1990s, 34 GA. L. REV. 1049, 1094 (2000). A Florida study finds the frequency of punitive damages awards to be "strikingly low." Neil Vidmar \& Mary R. Rose, Punitive Damages by Juries in Florida: In Terrorem and in Reality, 38 HaRv. J. LEGIS. 487, 487 (2001). See also Stephen Daniels \& Joanne Martin, Myth and Reality in Punitive Damages, 75 MINN. L. REV. 1 (1990) (two counties); Deborah Jones Merritt \& Kathryn Ann Barry, Is the Tort System in Crisis? New Empirical Evidence, 60 OHIO ST. L.J. 315, 388 (1999) (no punitive awards in medical malpractice or products liability cases in a twelve-year period in Franklin County, Ohio); NeIl Vidmar, Medical Malpractice and the American JuRy 254 (1995) (two punitive awards in 1,300 North Carolina medical malpractice cases).

${ }^{84}$ See, e.g. BJS 2000, supra note 77, at 1 (twenty-four percent of plaintiff winners in intentional tort trials receive punitive awards); BJS 1995, supra note 77, at 8; Landes \& Posner, supra note 74, at 185; Peterson et al., supra note 73, at 11, 35.

${ }^{85}$ Cass R. Sunstein et al., Assessing Punitive Damages (With Notes on Cognition and Valuation in Law), 107 Yale L.J. 2071, 2084 (1998). See, e.g., Landes \& Posner, supra note 74, at 209; A. Mitchell Polinsky \& Steven Shavell, Punitive Damages: An Economic Analysis, 111 HARV. L. REV. 869,909 n.120 (1998). 
the overwhelming evidence is that most such awards strongly correlate with compensatory damages in the same case. BJS data, GAO data, RAND data, and other data all reveal this correlation. ${ }^{86}$

The Exxon researchers' book fails to address the real world of punitive damages and relies exclusively on experimental evidence. That is a notable limitation in a project with effectively unlimited funding undertaken to influence social policy. The researchers did not try and reconcile their findings with the mass of data available from real cases. ${ }^{87}$ And subsequent efforts by Exxon researchers to show that punitive awards in large cases bear no relation to compensatory awards ${ }^{88}$ rely on flawed statistical methodology. ${ }^{89}$ The additional claim that punitive damages massively distort settlement patterns has so far not found empirical support. ${ }^{90}$

In short, the real world of punitive damages looks very different from the world a well-funded, self-interested actor can portray. Consider how lopsided the information in the punitive damages debate would be if access to archived or what will be archival data were unavailable. There would be no BJS data, no GAO data, no RAND data unless a jury verdict reporter happened to supply comprehensive reliable information. The data gathered and interpreted by Exxon's researchers, would dominate empirical knowledge about punitive damages. Even with substantial contrary data, Exxon researchers boldly claimed that "little was known" about how juries decide punitive damages "until recently," when the Exxon research was published. ${ }^{11}$ Such suppression of contrary social science information would become even more aggressive absent systematic access to archival data.

${ }^{86}$ Eisenberg et al., supra note 75, at 752-55 (BJS data); Eisenberg \& Wells, supra note 30, at 63739, 647-52 (BJS data); Theodore Eisenberg \& Martin T. Wells, The Predictability of Punitive Damages Awards in Published Opinions, the Impact of BMW v. Gore on Punitive Damages Awards, and Forecasting Which Punitive Awards Will Be Reduced, 7 SUP. CT. ECON. REV. 59 (1999); GAO Report, supra note, at 29 (punitive damages strongly correlate with compensatory damages); Erik K. Moller et al., Punitive Damages in Financial Injury Jury Verdicts, 28 J. LEGAL STUD. 283, 300 n.52 (RAND 1999); Jonathan M. Karpoff \& John R. Lott, Jr., On the Determinants and Importance of Punitive Damage Awards, 42 J. LAW \& ECON. 527, 543 (1999); Margo Schlanger, Inmate Litigation, 116 HARV. L. REv. 1555, 1605-05 \& n. 136 (2003); Catherine M. Sharkey, Dissecting Damages: An Empirical Exploration of Sexual Harassment Awards, $3 \mathrm{~J}$. EMPIRICAL LEGAL STUD. 1 (2006).

87 Theodore Eisenberg, Jeffrey Rachlinski, and Martin T. Wells, Reconciling Experimental Incoherence with Real-World Coherence in Punitive Damages, 54 STAN. L. REV. 1239 (2002).

${ }^{88}$ Joni Hersch \& W. Kip Viscusi, Punitive Damages: How Judges and Juries Perform, 33 J. Legal STUD. 1 (2004).

${ }^{89}$ Theodore Eisenberg \& Martin T. Wells, Analyzing Blockbuster Punitive Damages Awards: A Methodological Primer, 3 J. EMPIRICAL Legal STUD. 169 (2006).

${ }_{90}$ Thomas A. Eaton, David B. Mustard, and Susette M. Talarico, The Effects of Seeking Punitive Damages on the Processing of Tort Claims, 34 J. LEGAL STUD. 343 (2005).

${ }^{91}$ Brief, supra note 73, at 1 . 


\section{Class Actions}

Part I notes that little systematic knowledge about class actions exists. But one of the most comprehensive studies of class actions, the 2005 FJC study, shows little difference between state and federal court processing of class actions. The study came late in the debate over CAFA. With little solid information about class actions, self-interested groups stepped in to fill the gap. Defense class action attorneys report the results of an empirical study of class actions funded by the Manhattan Institute. ${ }^{92}$ The study is as noteworthy for what it did not include as for what it did include. With the resources available for such studies, the Manhattan Institute could have sought a broad-based sample covering many counties, could have sought to carefully track trends over time across a truly representative sample, and, as an FJC study, ${ }^{93}$ could have explored whether forum makes a difference in class certification decisions or class action case outcomes, as it seems to in the mass of litigation. ${ }^{94}$

Instead the study seems designed to support a preconceived conclusionthat certain small counties are the source of a national class action problem. The study was structured to avoid finding information about other counties. As reported by defense class action attorneys, the decision is portrayed as a neutral artifact of data availability.

The researchers ultimately elected not to conduct their reviews in the more populous counties identified in the class action literature search - Los Angeles County, California; Cook County, Illinois; and Dade County, Florida - for two reasons. First, these counties (by virtue of their size) had massive volumes of case filings (more than 45,000 per year in Dade County) and outdated filing systems that would have made it difficult to identify and retrieve class action dockets. Second, the larger metropolitan centers tend to experience higher volumes of more complex litigation of all sorts, limiting the ability to assess the specific impact of class actions in those judicial districts. $^{95}$

What a remarkable confluence of social science methodological limitations and self-interest.

The Manhattan Institute's campaign against class actions is well documented. $^{96}$ In what may be the Institute's most ambitious study of class actions, defense class action lawyers try to suggest that scientifically neutral considerations somehow led to counties constituting prime targets of the

\footnotetext{
${ }^{92}$ Beisner \& Miller, supra note 51.

${ }^{93}$ WILLGING \& WHEATMAN, supra note 44.

${ }^{94}$ Kevin M. Clermont \& Thedore Eisenberg, Exorcising the Evil of Forum Shopping, 80 CORNELL L. REV. 1507, 1507-35 (1995).

${ }^{95}$ Beisner \& Miller, supra note 51, at 159.

${ }^{96}$ See, The collection of Manhattan Institute projects cited in George L. Priest, What We Know and What We Don't Know About Modern Class Actions: A Review of the Eisenberg-Miller Study, 9 CIVIL JUSTICE REPORT 7 n.42 (Manhattan Institute 2005).
} 
Institute, Madison County, Illinois and Jefferson County, Texas, being the nearexclusive focus of the study. With no effort to gauge these counties' performance against any representative set of other counties, and with no effort to assess the quality of decisionmaking (were classes in fact improperly certified?) the study is the kind of junk science that should be rejected in court. It would not pass elementary tests of social scientific scrutiny. But of course that was not the point of the study. Empirical support was needed for an essentially political agenda. The Manhattan Institute is an able purveyor of the defense community's point of view. But its civil justice studies should not be confused with social science. Unless more neutral researchers are able to use archival and other data, selfpromoting research will fill the void.

\section{CONCLUSION}

Imagine making economic policy without knowledge or analysis of the Great Depression or of prior experience with inflation. Imagine making health care policy without systematic knowledge of past pandemics, epidemics, or toxic incidents. The legal system is an important social institution, perhaps as important in the long run to an orderly, well-functioning society as economic and health-care institutions. A society that prides itself as being one of laws depends on lawmakers being well-informed. It is time to regard systematic information about the legal system as being central to public policymaking. The choice is not one between reliable information and no information. It is too often a choice between reliable information and self-interested information masquerading as serious social scientific research - information that may be worse than having no information.

The core claims of this pseudo social science have been refuted by the archival record. Tort awards have not soared over decades, punitive damages are not frequently and irrationally awarded, litigiousness of citizens is vastly overstated, and claims about differences in federal and state court willingness to certify class actions remain unproven. Even with contrary information available, the relentless message of pseudo social science appears to substantially influence policy. Without archival information about the legal system, the message would be that much more influential. 